\title{
Chronic pain following inguinal herniorrhaphy: perceptions of children and adolescents*
}

\section{Dor crônica após herniorrafia inguinal: percepções de crianças e adolescentes Dolor crónico tras hernia inguinal: percepciones de niños y adolescentes}

How to cite this article:

Moura LA, Oliveira PR, Medeiros M, Rossato LM, Borges NC, Pereira LV. Chronic pain following inguinal herniorrhaphy: perceptions of children and adolescents. Rev Esc Enferm USP. 2021;55:e20200490. doi: https://doi.org/10.1590/1980-220X-REEUSP-2020-0490

\section{Louise Amália de Moura ${ }^{1}$ \\ Pâmela Roberta de Oliveira ${ }^{2}$ \\ Marcelo Medeiros ${ }^{3}$ \\ iD Lisabelle Mariano Rossato ${ }^{4}$ \\ Natália de Carvalho Borges ${ }^{3}$ \\ Lilian Varanda Pereira ${ }^{3}$}

* Extracted from the dissertation: "Dor crônica pósoperatória em crianças submetidas à herniorrafia inguinal: uma coorte prospectiva”, Universidade Federal de Goiás, Faculdade de Enfermagem, Programa de Pós-Graduação em Enfermagem, 2019.

${ }^{1}$ Instituto Federal de Goiás, Câmpus Goiânia Oeste, Goiânia, GO, Brazil.

${ }^{2}$ Universidade Federal de Mato Grosso, Faculdade de Enfermagem, Cuiabá, MT, Brazil.

${ }^{3}$ Universidade Federal de Goiás, Faculdade de Enfermagem, Goiânia, GO, Brazil.

${ }^{4}$ Universidade de São Paulo, Escola de Enfermagem, São Paulo, SP, Brazil.

\begin{abstract}
Objective: To analyze the perceptions of children and adolescents about chronic postsurgical pain, experienced for three years after outpatient inguinal herniorrhaphy Method: Descriptive, exploratory study, with a qualitative approach. Children and adolescents who reported chronic postsurgical pain were invited from previous quantitative research. The interviews with a semi-structured script were recorded, transcribed, and coded according to content analysis, thematic modality. Results: Twenty children and teenagers participated. They attributed different meanings to chronic persistent postsurgical pain, configuring a bad, uncomfortable, intermittent and limiting experience, which socially isolates, interferes with daily, school, and leisure activities. The report of pain was underestimated and neglected by the children's and adolescents' healthcare team, family members, teachers, and friends. Conclusion: Children and adolescents recognize postsurgical pain as persistent pain and seem to perceive that their report is underestimated and neglected by parents and teachers. Additionally, they feel responsible for the presence of pain that affects psychological and social dimensions and imposes damage and fear that leads to the return of the hernia and to death.
\end{abstract}

\section{DESCRIPTORS}

Child; Adolescent; Chronic Pain; Pain, Postoperative; Hernia, Inguinal; Pediatric Nursing.
Corresponding author:

Louise Amália de Moura

Rua 227, Quadra 68, Setor Universitário

74605-080 - Goiânia, GO, Brazil

louiseamoura@gmail.com
Received: $11 / 18 / 2020$

Approved: 04/22/2021 


\section{INTRODUCTION}

The first painful experiences in a person's life, when poorly managed or underestimated, can result in negative effects that persist throughout adulthood, such as chronic pain and suffering ${ }^{(1)}$. Currently, despite the tools and scientific evidence supporting and favoring the treatment of childhood pain, this experience still remains undertreated ${ }^{(1)}$. This is because the knowledge of healthcare professionals about the painful experience, especially pediatric pain, has been pointed out as limited ${ }^{(2)}$.

Chronic postsurgical pain (CPSP), for instance, is a public health problem recognized in the pediatric population ${ }^{(3)}$. CPSP is pain that develops or increases in intensity and persists for at least three months after a surgical procedure, such as open herniorrhaphy ${ }^{(4)}$. Herniorrhaphy, a traditional repair that does not use a mesh for closure, is one of the most commonly performed outpatient surgical procedures ${ }^{(5)}$. After an inguinal herniorrhaphy (IHR), evidence points to a higher risk of CPSP compared to other surgeries of the same complexity performed in childhood ${ }^{(6)}$.

Longitudinal studies have shown children with pain in the inguinal region after a mean follow-up period of six (6) months ${ }^{(6)}$ and 3.2 years after $\operatorname{IHR}^{(7)}$. Even in the long term, many children experience severe CPSP after IHR, which interferes with daily activities ${ }^{(7)}$ and implies physical disability and poor sleep quality ${ }^{(6)}$. Another evidence highlighted is that CPSP causes damage that tends to persist during most part of childhood, adolescence, and adulthood ${ }^{(8)}$. For example, chronic pain can be a critical factor in the development of depression in adolescents ${ }^{(9)}$. In this context, knowing the perceptions of children and adolescents about CPSP is essential to broaden the understanding of risk factors involved in the development and maintenance of this pain, such as sex, age, preoperative pain, postoperative pain, genetics, psychological and surgical factors (nerve injuries) ${ }^{(10)}$.

Studies with a qualitative approach on this theme are limited and little is known about the symbolic meaning of pain for children and adolescents living with CPSP after outpatient surgery. Additionally, a gap in the availability of evidence related to chronic pain self-report in children and adolescents was pointed out ${ }^{(11)}$. In a study reporting chronic pain experiences of children, adolescents, and their families, surgery was identified as stressful. The lack of information related to pain and long-term recovery was addressed, as well as emotional challenges ${ }^{(12)}$. Studies describing the children's and adolescents' experiences in details, in different aspects of living with CPSP following outpatient surgery, were not found; thus, this study brings the innovation of presenting the symbolic meanings of CPSP for children and adolescents and of contributing to healthcare professionals, especially nurses, in the long-term management of pediatric chronic pain.

This research is based on the theoretical framework of the biopsychosocial model of pain, which considers it to be a complex interaction among multiple biological, psychological, and sociocultural factors ${ }^{(13)}$. Based on this premise, the following research question was established: "What are the perceptions of children and adolescents about chronic postsurgical pain, experienced for three years after outpatient inguinal herniorrhaphy?" Aiming to answer this question, the aim of the study was to analyze the perceptions of children and adolescents about chronic postsurgical pain, experienced for three years after outpatient inguinal herniorrhaphy.

\section{METHOD}

\section{Type OF Study}

This is a descriptive exploratory study with a qualitative approach, which had as its starting point the definition of a previous quantitative-based research conducted with children and adolescents in the city of Goiânia-Brazil. Data were analyzed by content analysis, thematic modality. To promote rigor, coverage, and credibility of the interview study, we follow COREQ (Consolidated Criteria For Reporting Qualitative Research) guidelines.

\section{LOCAL}

The locus of the study consisted of two spaces, both in the city of Goiânia-Brazil. The first one included two hospitals that offered outpatient pediatric surgical care, where participants were invited and subsequently followed up in the postoperative period. The second one was the Nursing School at Universidade Federal de Goiás, where children and adolescents with CPSP went to for an individual interview.

\section{Selection Criteria}

Children and adolescents aged between 8 and 15 years, of both genders, who underwent IHR three years ago, with a report of CPSP, defined as intermittent or continuous pain in the inguinal region of the operated side, were included. Children in this age group are able to produce information in semi-structured interviews ${ }^{(14)}$. Children who underwent another surgical procedure during follow-up were excluded.

\section{Data Collection}

Based on a cohort study, the researcher contacted those responsible for the possible participants, that is, those who persisted with a report of pain at the surgical site three years or more after IHR. This contact was established through a telephone call between July and November 2017, inviting the individuals to a clinical examination (specialized nursing and neuropediatrics assessment) and a personal interview.

First, the purpose of the study was reminded and the parents/guardians signed the Free Informed Consent Form. The children and adolescents signed the Free Informed Assent Term. The participants' sociodemographic characteristics were obtained through an elaborate script based on scientific evidence.

The interviews were conducted individually by the researcher in a private room. The semi-structured script contained the following questions: 1) What is pain for you (physical pain - pain you feel in the body)? And persistent pain, that pain that does not go away with time, what do 
you think of it? 2) And why do you think this pain didn't disappear after the surgery? 3) How do people react when you talk about this pain? 4) Do you want to say anything else about this pain?

There was a single interview and it was recorded on a voice recorder. Participants spoke freely, with no time constraints. The average duration of the interviews was approximately 10 minutes. Regarding the duration of the interview, we shall consider the uniqueness of the pediatric age group and that, despite the annual telephone contacts made by the interviewer, this was the first personal contact with the children/ adolescents in the late postoperative period. Moreover, we understand that interviews with children, unlike interviews conducted with adults, shall be more informal and less structured to provide them with greater control ${ }^{(14)}$.

The study followed the qualitative data saturation criteria $^{(15)}$, which allow for the inclusion of participants until the objectives are achieved, no new theme is established, or until there are no new questions within the categories or themes.

\section{Data Analysis and Treatment}

Data analysis was based on the theoretical framework of content analysis, a thematic modality comprising three steps: pre-analysis, material exploration, and treatment of results ${ }^{(16)}$. After the literal transcription of all voice recordings, a thematic analysis was performed, oriented by a guiding script for the qualitative data analysis process ${ }^{(17)}$, set in the logical-semantic field, with exhaustive reading of the collected content. The analytical process of this study was systematized $^{(17)}$, according to the paragraphs described below.

The first step, pre-analysis, comprised the exploration of the material, through vertical readings of the transcribed interviews corpus, to apprehend and organize important aspects of the content and its logic ${ }^{(17)}$. In the second step, the material was horizontally read, highlighting the lines and/or excerpts representing the central ideas ${ }^{(17)}$. Some words assumed greater importance, as they appeared more frequently in the speeches, and were grouped by similarity and/or approximation, forming the Nuclei of Meaning (NS) ${ }^{(17)}$. Following coding, in the third step, a descriptive synthesis was elaborated for each NS and grouped by themes ${ }^{(17)}$, from which the categories "Pain waxes and wanes", "Pain is a lie", "Limiting pain" emerged. Data were presented and discussed through selection and illustrative citation of the speech fragments, followed by a brief description, inference, and interpretation ${ }^{(17)}$.

\section{Ethical Aspects}

The study was approved by the Research Ethics Committee of Hospital das Clínicas, Universidade Federal de Goiás (opinion No. 1.398.953/2016). The ethical requirements of Resolution 466/2012, of the National Health Council, were met. All parents/guardians signed the Free Informed Consent Form and all children and adolescents voluntarily agreed to participate in the interview. To ensure anonymity, participants in this study were coded with the letter "C" and numbered according to the order in which the interviews were conducted.

\section{RESULTS}

\section{Participants Characterization}

A total of 20 children and adolescents agreed to participate in the study. The median age of participants was 10.5 years and most were women (55\%). Among the participants, $85 \%$ reported talking about their pain to a family member. The average time from surgery to the interview was $36.5 \pm 0.4$ months.

\section{Pain Waxes And Wanes}

Children and adolescents seemed to recognize the pain felt at the surgical site as persistent, a pain that did not disappear over time. Some thought the surgery would correct the pain felt at the hernia site, but it did not. The statements also reveal that CPSP has an intermittent characteristic, as it waxes and wanes at interspersed times and days.

Yes [persistent], because I'm constantly feeling it (C18).

Because it's been three years since I underwent surgery and even now, from time to time, I have pain (C10).

I think so [that it is persistent] (...) it comes in one day, then it goes for two days, and comes again (C15).

Understanding the cause of CPSP did not seem to be clear to children and adolescents. Reports pointed out aspects related to beliefs, to the surgical procedure (anesthesia), and to daily activities performed by children and adolescents, including playing, running, or holding objects, as the causes of CPSP persistence:

Because I play (C20).

I think it was some anesthesia we took or something else (...) I thought it was normal (C4).

It had a reason to be showing up. I think that [the pain] should have disappeared, but it also depends on what I do, then as I sometimes lift weight (...) (C6).

Still on the cause of CPSP, some participants highlighted external factors in relation to the persistence of pain after IHR, such as the surgical procedure itself.

The doctor said that it was because of the surgery, that I would feel pain for the rest of my life, I was kind of like that, you know (...) [sadness]. What will I do? (C5)

This surgery was not what they thought, then this hernia pain, they couldn't remove this hernia pain, so it kept insisting, you know [the pain], then to remove it, I'll have to undergo another surgery (...) (C9).

\section{The Pain Is A Lie}

Children's and adolescents' speeches show that CPSP was discredited over the months following IHR.

My mother, from time to time, doesn't believe it (C12). 
Then I told my teacher that I was in pain and she didn't believe it, she said I was lying, that it wasn't true (C6).

(...) girl, stop lying, you only come here to lie, just to leave (C1).

A teenager highlighted that the explanation about the surgery was necessary to validate her pain report:

Ah, many times, people keep saying, oh you're lying, only when I say I had the surgery, then they believe me $(\mathrm{C} 1)$.

In addition, children and adolescents reported that people in daily contact such as parents and teachers overlook CPSP. Feelings of fear and helplessness were highlighted in the face of the undervaluation and invisibility of the painful experience:

I'm afraid (...) then there's the thought that I'm going to die, I'm going to faint, then my mother forgets about me (C12).

Let me go [to the bathroom], teacher, because I underwent a surgery, it hurts! - No! You have to wait for the time, I want to let you go, but if I do, the consequences are for me (C16).

I was afraid to tell someone [about the pain] at school (...) having this hernia thing is dangerous, then I was afraid to talk (C9).

\section{Limiting PAin}

Several reports from children and adolescents express the limitations imposed by persistent pain at the surgical site, which include daily activities, including those that require movement and social relationships:

I was running (...) then the pain came, I stopped (...) the pain came very strong, then I couldn't play anymore (C17).

When I'm lying there on the couch to watch $T V$, the pain comes really strong, I can't bear it $(\mathrm{C} 12)$.

(...) if I run too much, I'll feel that same pain, and it's not good sometimes, I run because I forget. You know? In the moment of joy, with my friends (C7).

The influence of CPSP on school performance was also identified, as reported below:

At school, I sneezed and it hurt. The pain remained. When it was hurting, I didn't concentrate on the study $(\mathrm{C} 8)$.

Sometimes it hurts when I'm running, in physical education (C12).

I was studying, because I was going to take a test, then it started to burt... then I went to the secretary (...) (C19).

\section{DISCUSSION}

The results of this research show that children's and adolescents' perceptions confirm the persistence of postoperative pain three years after undergoing IHR. They express the undervaluation of pain report and the damages arising from this experience in carrying out daily activities and in the relationship with parents, family, teachers, health professionals, and friends. Different meanings can be attributed to CPSP, according to biopsychosocial factors, such as age, cognitive level, personality type, life history and previous experiences with pain, way of seeing the world, beliefs, culture, personal pain coping strategies, family life, surgical procedure, among others.

The persistence of pain is a bad and uncomfortable experience that leads children and adolescents to question why the pain has not disappeared if the surgery was performed to help them. It seems that surgery becomes the cause of pain and not a solution for it. This gap left by doubt and questioning is amplified by assumptions and self-blame that seek justification for the suffering and discomfort that pain has caused. The results complement data on pain experiences reported by children and adolescents undergoing major surgeries ${ }^{(10)}$.

In this study, children and adolescents perceive that the persistence of postoperative pain is attributed to them by the fact that they carry out activities that require movement such as studying, walking, relating to friends, picking up objects and people, even playing instead of staying at rest. This way, there is guilt in the speech of $C 20$ (8 years old), related to the act of playing, with an evident negative feeling associated with chronic pain. Playing is essential for child development; through play, resilience, growth and physical, cognitive, emotional and social skills are developed; therefore, regardless of a child's socioeconomic status, the benefits of playing shall be recognized ${ }^{(18)}$.

From this perspective, it is clear that CPSP transposes the biophysiological aspect, as it has affected other important dimensions in these children and adolescents lives, such as the social and psychological dimensions. Moreover, data expose the fragility present in the communication among the healthcare team, the patient, and their family.

Additionally, regarding the guilt that children and adolescents feel for the onset of pain, it is noteworthy that family members and health professionals have reinforced this feeling in some situations. This suggests a lack of knowledge about the progression of the problem and probable anxiety regarding the limitation itself of providing adequate pain relief. The statements reinforce the statements that children's cognitions and beliefs about pain, including fear and avoidance behaviors, develop in the family context ${ }^{(19-20)}$. Other researchers also agree that the recovery of adolescents who report CPSP after surgery can be influenced by the family and professionals ${ }^{(12)}$.

In the participants' perception, the type of surgery also contributed to the genesis of the painful experience. Regarding such conceptions, although guilt is centered on the child and adolescent themselves, these perceptions can be justified if we bring to the scene evidence about the factors that can evoke CPSP. For example, touching a surgical wound, movement, breathing, coughing, or gastrointestinal activity; when there is neuron hyper-responsiveness, innocuous stimuli start to activate the transduction and neuronal transmission of stimuli perceived as painful ${ }^{(21)}$. In addition, trauma to nervous structures during surgeries performed in childhood and adolescence are more frequent than in younger participants, and they mention persistent pain with a neuropathic element ${ }^{(22)}$. 
Regarding the damage caused by chronic pain, in this study, emotional and social factors, which involve the persistence of pain, were identified with strong meaning for children and adolescents, as they generate limitation and deprivation. In a systematic review with meta-analysis, pre-surgical biological, medical, and psychosocial factors associated with the prevalence or severity of CPSP in children and adolescents were identified ${ }^{(10)}$. Other evidence points to a strong connection between the feeling of anxiety and persistent pain in adolescents ${ }^{(23)}$.

Furthermore, there is an impediment to participating in favorite activities, including sports and extracurricular activities, which can lead to the loss of positive reinforcement and friendships, as well as low self-esteem ${ }^{(24)}$. In addition, school impairment associated with cognitive, psychological and social factors can be evaluated in children and adolescents with chronic pain ${ }^{(25)}$.

The fear of pain emerged as an important perception of children and adolescents, referring to the anticipation of death and leading to helplessness and loneliness, permeated by the undervaluation of what they reported feeling.

In this regard, the study emphasized the importance of communication and education about pain for parents and the pediatric population, which means that parents need to be committed to the process of understanding, in a more integral way, the child or adolescent pain, which also allows for adjustments in parents' potentially harmful attitudes and behaviors towards the child ${ }^{(20)}$.

Likewise, CPSP seemed "common" in the speeches of some children and adolescents. This idea was reinforced by a healthcare professional who emphasized that adolescents would have to live with lifelong pain. Researchers show that children with chronic pain are subject to misperceptions by healthcare professionals, especially when the pain is of a psychological nature ${ }^{(26)}$.

Nevertheless, the literature review results highlighted important negative aspects of care provided to children and adolescents with chronic pain, including delay in referring them to pediatric pain specialists and failure to recognize psychological disorders as common comorbidities in children and adolescents with pain ${ }^{(27)}$. These positions of family members and healthcare professionals contribute to delayed pain relief, as well as to constant deterioration in quality of life ${ }^{(28)}$, perpetuating unnecessary suffering.

Reinforcing the failures in the management of CPSP, the findings also point out that the child's or adolescent's report of pain is not always valid for parents and teachers. This is evident in the speech by $C 17$, when she emphasizes that pain is only "accepted" after informing about the surgery she underwent. Thus, pain is only conceived as legitimate when it is materialized, that is, the painful complaint is only considered true due to an injury or disease $^{(29)}$. Such misunderstanding about the painful experience still permeates the clinical environment and contributes to pain undertreatment. In this context, it is clearly recognized that there is a wide gap in the educational training of healthcare professionals on pediatric pain control $^{(2)}$.
Nurses have a fundamental role in pediatric pain management and, therefore, they shall understand aspects of the biopsychosocial approach to the painful experience ${ }^{(2)}$. In this aspect, the importance of nursing intervention in the multidimensional assessment of pain and the need to provide detailed and clear information to children, adolescents, and their families about surgery, pain and recovery are reinforced ${ }^{(12)}$.

Some feasible strategies can be considered in the management of chronic pain in children and adolescents, such as giving importance to reported pain, understanding the social and cultural context of pain; also, making pain visible through multidimensional assessment focusing on positive results in the context of the pediatric population, and prioritizing pain improvement and relief through treatments in different areas of knowledge $\mathrm{e}^{(1)}$.

These findings can provide support for planning interventions that include the development of pain coping skills with the aim of improving child and adolescent recovery. Additional research, especially in the nursing field, involving parents, multidisciplinary health teams and schools, is required to develop evidence on the role of these individuals in the maintenance of CPSP in children and adolescents.

In qualitative research, we understand that the limitations are relative, especially in this study that sought to analyze the perceptions of children and adolescents; however, the parents' perceptions were not investigated, which refers to the possibility of expansion of this study. Furthermore, although the annual telephone contacts made by the researcher have allowed for a minimum and periodic interaction with the children, this circumstantial approximation may have restricted the bond between them, influencing the time of the interviews (on average 10 minutes), although the children were free to talk about their pain. Such limitation may be related to the age of the participants, who tend to be more objective in their answers.

We highlight the pioneering nature of this study of exploring the perceptions of Brazilian children and adolescents with CPSP following outpatient IHR, as it addresses an important gap and adds knowledge to the pediatric literature by providing a description of the symbolic meaning of CPSP based on the children's and adolescents' self-reports. We believe that the findings are a source of useful and valid information about the importance of pain management, based on the influence of biopsychosocial factors. Nurses are professionals who shall actively participate in the assessment and individualized treatment of CPSP in children and adolescents, especially after long-term discharge to home, which can be done in Primary Care, via the Family Health Strategy. These findings can also be used as grounds for educational and pain management practices.

\section{CONCLUSION}

Pain felt three years after IHR is recognized as persistent by children and adolescents, who feel co-responsible for continuing to experience pain for a long time after 
surgery. Additionally, parents and teachers underestimate and neglect the report of pain, and the biopsychosocial factors attributed to the persistence of pain, including fear which refers to the return of the hernia and to death. CPSP socially isolates, interferes with daily, school, and leisure activities, imposing damages, including playing, an important activity for the good children physical and mental development. Findings present symbolic meanings of CPSP and offer support for achieving adequate chronic pain management in pediatrics.

\section{RESUMO}

Objetivo: Analisar as percepções de crianças e adolescentes sobre dor crônica pós-operatória, vivenciada durante três anos após herniorrafia inguinal ambulatorial. Método: Estudo descritivo, exploratório e de abordagem qualitativa. Crianças e adolescentes que referiram dor crônica pós-operatória foram convidados a partir de pesquisa quantitativa anterior. As entrevistas com roteiro semiestruturado foram gravadas, transcritas e codificadas segundo a análise de conteúdo, modalidade temática. Resultados: Participaram 20 crianças e adolescentes. Eles atribuíram diferentes significados à dor crônica pós-operatória persistente, configurando uma experiência ruim, incômoda, intermitente e limitante, que isola socialmente, interfere nas atividades cotidianas, escolares e de lazer. O relato de dor foi subestimado e negligenciado pela equipe de saúde, familiares, professores e amigos das crianças e adolescentes. Conclusão: Crianças e adolescentes reconhecem a dor pós-operatória como dor persistente e parecem perceber que seu relato é subestimado e negligenciado pelos pais e professores. Adicionalmente, sentem-se responsáveis pela presença da dor que afeta dimensões psicológicas e sociais e impõe prejuízos e medo que remete ao retorno da hérnia e à morte.

\section{DESCRITORES}

Criança; Adolescente; Dor Crônica; Dor Pós-Operatória; Hérnia Inguinal; Enfermagem Pediátrica.

\section{RESUMEN}

Objetivo: Analizar las percepciones de niños y adolescentes sobre dolor crónica posoperatoria, vivenciada durante tres años tras hernia inguinal ambulatoria. Método: Estudio descriptivo, exploratorio y de abordaje cualitativo. Niños y adolescentes que relataron dolor crónico posoperatorio fueron invitados desde investigación cualitativa anterior. Las entrevistas con texto semiestructurado fueron grabadas, transcriptas y codificadas según el análisis de contenido, modalidad temática. Resultados: Participaron 20 niños y adolescentes. Ellos atribuyeron diferentes significados al dolor crónico posoperatorio persistente, lo configuraron como una experiencia mala, incomoda intermitente y limitante, que genera aislamiento social, interfiere en las actividades cotidianas, escolares y de ocio. El relato de dolor fue subestimado y negligenciado por el equipo de salud, familiares, profesores y amigos de los niños y adolescentes. Conclusión: Niños y adolescentes reconocen el dolor posoperatorio como dolor persistente y parecen percibir que su relato es subestimado y negligenciado por los padres y profesores. Además, se sienten responsables por la presencia del dolor que afecta dimensiones psicológicas y sociales e impone perjuicios y miedo que remite al regreso de la hernia y la muerte.

\section{DESCRIPTORES}

Niño; Adolescente; Dolor Crónico; Dolor Postoperatorio; Hernia Inguinal; Enfermería Pediátrica.

\section{REFERENCES}

1. Eccleston C, Fisher E, Howard RF, Slater R, Forgeron P, Palermo TM, et al. Delivering transformative action in paediatric pain: a Lancet Child \& Adolescent Health Commission. Lancet Child Adolesc Health. 2021;5(1):47-87. https://doi.org/10.1016/S2352-4642(20)30277-7

2. Hurley-Wallace A, Wood C, Franck LS, Howard RF, Liossi C. Paediatric pain education for health care professionals. Pain Rep. 2019;4(1):e701. http://dx.doi.org/10.1097/PR9.00000000000007014

3. Williams G, Howard RF, Liossi C. Persistent postsurgical pain in children and young people: prediction, prevention, and management. Pain Rep. 2017;2(5):e616. http://dx.doi.org/10.1097/PR9.0000000000000616

4. Schug SA, Lavand'Homme P, Barke A, Korwisi B, Rief W, Treede R, et al. The IASP classification of chronic pain for ICD-11: chronic postsurgical or posttraumatic pain. Pain. 2019;160(1):45-52. http://dx.doi.org/10.1097/j.pain.0000000000001413

5. Lockhart K, Dunn D, Teo S, Ng JY, Dhillon M, Teo E, et al. Mesh versus non-mesh for inguinal and femoral hernia repair. Cochrane Database Syst Rev. 2018;9(9):CD011517. http://dx.doi.org/10.1002/14651858.CD011517.pub2

6. Mossetti V, Boretsky K, Astuto M, Locatelli BG, Zurakowski D, Lio R, et al. Persistent pain following common outpatient surgeries in children: a multicenter study in Italy. Paediatr Anaesth. 2018;28(3):231-6. http://dx.doi.org/10.1111/pan.13321

7. Kristensen $\mathrm{AD}$, Ahlburg $\mathrm{P}$, Lauridsen $\mathrm{MC}$, Jensen TS, Nikolajsen L. Chronic pain after inguinal hernia repair in children. Br J Anaesth. 2012;109(4):603-8. http://dx.doi.org/10.1093/bja/aes250

8. Incledon E, O'Connor M, Giallo R, Chalkiadis GA, Palermo TM. Child and family antecedents of pain during the transition to adolescence: a longitudinal population-based study. J Pain. 2016;17(11):1174-82. http://dx.doi.org/10.1016/j.jpain.2016.07.005

9. Wicksell RK, Kanstrup M, Kemani MK, Holmström L. Pain interference mediates the relationship between pain and functioning in pediatric chronic pain. Front Psychol. 2016;7:1978. http://dx.doi.org/10.3389/fpsyg.2016.01978

10. Rabbitts JA, Fisher E, Rosenbloom BN, Palermo TM. Prevalence and predictors of chronic postsurgical pain in children: a systematic review and meta-analysis. J Pain. 2017;18(6):605-14. http://dx.doi.org/10.1016/j.jpain.2017.03.007

11. Birnie KA, Hundert AS, Lalloo C, Nguyen C, Stinson JN. Recommendations for selection of self-report pain intensity measures in children and adolescents: a systematic review and quality assessment of measurement properties. Pain. 2019;160(1):5-18. http://dx.doi.org/10.1097/j. pain.0000000000001377

12. Rabbitts JA, Aaron RV, Fisher E, Lang EA, Bridgwater C, Tai GG, et al. Long-term pain and recovery after major pediatric surgery: a qualitative study with teens, parents, and perioperative care providers. J Pain. 2017;18(7):778-86. http://dx.doi.org/10.1016/j.jpain.2017.02.423 
13. Turk DC, Okifuji A. Psychological factors in chronic pain: evolution and revolution. J Consult Clin Psychol. 2002;70(3):678-90. https:// doi.org/10.1037/0022-006X.70.3.678

14. Kortesluoma RL, Hentinen M, Nikkonen M. Conducting a qualitative child interview: methodological considerations. J Adv Nurs. 2003;42(5):434-41. https://doi.org/10.1046/j.1365-2648.2003.02643.x

15. Strauss A, Corbin J. Basics of qualitative research. Thousand Oaks: Sage; 2015. p.139-40.

16. Bardin DL. Análise de conteúdo. São Paulo: Edições 70; 2016.

17. Ferreira AMD, Oliveira JLC, Souza VS, Camillo NRS, Medeiros M, Marcon SS, et al. Adapted guide of content analysis - thematic modality: report of experience. J Nurs Health. 2020;10(1):e20101001. http://dx.doi.org/10.15210/jonah.v10i1.14534

18. Yogman M, Garner A, Hutchinson J, Hirsh-Pasek K, Golinkoff RM; Committee on Psychosocial Aspects of Child and Family Health and Council on Communications and Media. The importance of play in promoting healthy child development and maintaining strong parentchild bond: focus on children in poverty. Pediatrics. 2018;142(3):e20182058. https://doi.org/10.1542/peds.2018-2058

19. Riggenbach A, Goubert L, Petegem SV, Amouroux R. Topical review: basic psychological needs in adolescents with chronic pain-a selfdetermination perspective. Pain Res Manag. 2019;2019:8629581. https://doi.org/10.1155/2019/8629581

20. Koechlin H, Locher C, Prchal A. Talking to children and families about chronic pain: the importance of pain education - an introduction for pediatricians and other health care providers. Children (Basel). 2020;7(10):179. http://dx.doi.org/10.3390/children7100179

21. Kehlet $\mathrm{H}$, Jensen TS, Woolf CJ. Persistent postsurgical pain: risk factors and prevention. Lancet. 2006;367(9522):1618-25. http://dx.doi. org/10.1016/S0140-6736(06)68700-X

22. Fitzgerald M, McKelvey R. Nerve injury and neuropathic pain: a question of age. Exp Neurol. 2016;275:296-302. http://dx.doi. org/10.1016/j.expneurol.2015.07.013

23. Sørensen K, Christiansen B. Adolescents' experience of complex persistent pain. Scand J Pain. 2017;15:106-12. http://dx.doi.org/10.1016/j. sjpain.2017.02.002

24. Landry BW, Fischer PR, Driscoll SW, Koch KM, Harbeck-Weber C, Mack KJ, et al. Managing chronic pain in children and adolescents: a clinical review. PM R. 2015;7(11 Suppl):S295-S315. http://dx.doi.org/10.1016/j.pmrj.2015.09.006

25. Jones K, Nordstokke D, Wilcox G, Schroeder M, Noel M. The 'work of childhood': understanding school functioning in youth with chronic pain. Pain Manag. 2018;8(2):139-53. http://dx.doi.org/10.2217/pmt-2017-0048

26. Betsch TA, Gorodzinsky AY, Finley GA, Sangster M, Chorney J. What's in a name? Health care providers' perceptions of pediatric pain patients based on diagnostic labels. Clin J Pain. 2017;33(8):694-8. http://dx.doi.org/10.1097/AJP.0000000000000454

27. Cucchiaro G, Schwartz J, Hutchason A, Ornelas B. Chronic pain in children: a look at the referral process to a pediatric pain clinic. Int J Pediatr. 2017;2017:8769402. http://dx.doi.org/10.1155/2017/8769402

28. Miró J, McGrath PJ, Finley GA, Walco GA. Pediatric chronic pain programs: current and ideal practice. Pain Rep. 2017;2(5):e613. http:// dx.doi.org/10.1097/PR9.0000000000000613

29. Turkmen AS, Sahiner NC, Koroglu AY, Inal S. Pain and factors that affect its definition as defined by preschool age children: a qualitative study. Rev Eletr Enf. 2018;20:a34. http://dx.doi.org/10.5216/ree.v20.49441 